\title{
Assessing Bill C-36: The Myth of Inalienable Human $\underline{\text { Rights }}$
}

Natalie Falcomer

Wilfrid Laurier University

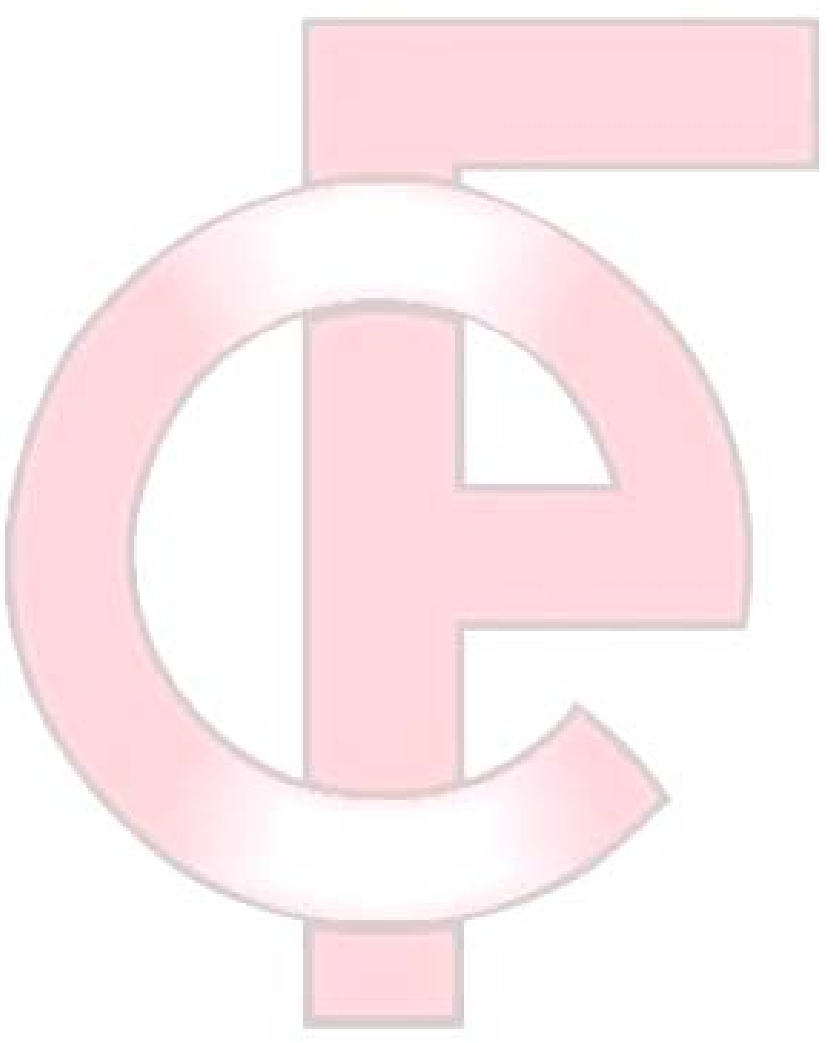

As an Honours Political Science and History student, Natalie Falcomer has pursued her interests in politics as an active Ontario Young Liberal and member of the Anti Trafficking Initiative. Natalie seeks to make a difference in her community as a founder of a public speaking organization Toastmasters Club - and organizer of International Women's Week and The Sex Slave Trade Awareness Campaigns at Wilfrid Laurier University. She hopes to continue her education through pursuing a law degree in International Human Rights. 
"[T] he dilemma of justice for legislators and judges is to determine when equal treatment for all is the fair and proper thing, and when, on the other hand, some discriminations are necessary and fair."1

The concept of human rights circumvents an exact definition and despite its universal acceptance there is a lack of agreement on how it should be approached. ${ }^{2}$ Human rights may be defined as inalienable rights which are acquired purely by virtue alone. In comparison, some scholars view human rights in a "strict legal sense" as such rights are created by contract or statute and are therefore, "removable or alterable." ${ }^{\text {"3 }}$ The dominant notion of human rights accepts the theory of "natural rights" as political, legal, economic and egalitarian rights which are both morally and legally justifiable. ${ }^{4}$ More importantly, it is argued that these abstract principles only become relevant as they are codified in detailed legislation, otherwise, "they remain incomplete and ineffective in affording

\footnotetext{
1 Wayne MacKay, "Regulating Freedom of Expression the Canadian Way," in Canadian Constitutional Dilemmas Revisited, ed. Denis N. Magnusson and Daniel A. Soberman. (Kingston, Ontario: Institute of Intergovernmental Relations, 1997), 73.

2 Nancy Holmes, "Human Rights and the Courts in Canada," Law and Government Division, Depository Services Program, October 2001, http://dsp-psd.pwgsc.gc.ca.remote.libproxy.wlu.ca/CollectionR/LoPBdP/BP/bp279-e.htm (accessed March 3, 2006).

3 Idem

4 Idem.
}

meaning and direction at the level of everyday affairs." ${ }^{5}$

To legitimize the abstract values of human natural rights, the creation of laws and the protection, implementation and promotion of human rights are subject to public policy and government intervention. ${ }^{6}$ The Canadian Charter of Rights and Freedoms (1982), as well as other federal and provincial substantive and procedural legislation, establishes a legal force where a positive relationship exists between the citizens and the state. Although many vital rights and freedoms are essential concepts in present-day Canadian legislation, the application of natural rights may be limited by social, economic or political factors and context; discrimination may be necessary and fair in order to balance opposing rights and freedoms with the safety of society. ${ }^{7}$ Regardless of such possible encroachments on fundamental rights, there is a deep tradition and rich history of Canadian citizens looking to

\footnotetext{
${ }^{5}$ Wayne MacKay, Loc. Cit.,73.

${ }^{6}$ Nancy Holmes, Loc. Cit.

7 Wayne MacKay, Loc. Cit., 73-74. This tension is reflected in the Supreme Court decisions where obscenity and hate propaganda is not treated as equal to the constitutional values of freedom of speech. Professor Lederman of Dalhousie Law School and Queen's Faculty of law points to the Butler and Keegstra case to support the use of such necessary discrimination...
} 
the government to protect their rights and promote society's broader interests. ${ }^{8}$

\section{Evolution of Canada's Human Rights System}

The Canadian human rights system reflects a mix of British and American traditions where human rights protection relies on statute laws and elected parliaments in addition to the use of judicial review and a written constitution. ${ }^{9}$ This system outlines the various periods of the Canadian experience in which the evolution of human rights mechanisms took place.

The first period - from Confederation to 1960 - relied on federal and provincial legislatures to safeguard human rights which emanated from the common law established in the United Kingdom. The judicial branch played a small role and both the legislatures and courts were hesitant to address violations of human rights except as peripheral matters. Moreover, the Constitution Act 1867 did not establish any specific rights or fundamental liberties; however, section 92 (13) provided provincial lawmakers with jurisdiction over "property and civil rights" and the Act also

\footnotetext{
${ }^{8}$ Rt. Hon. Kim Campbell, "Parliament's Role in Protecting the Rights and Freedoms of Canadians", in Protecting Rights and Freedoms: Essays on the Charter's Place in Canada's Political, Legal, and Intellectual Life, ed. Philip Bryden et al. (Toronto: University of Toronto Press Incorporated, 1994): 23-30.

${ }^{9}$ Nancy Holmes, Loc. Cit.
}

guaranteed some minority rights regarding the use of the French and English language and the operation of Roman Catholic and Protestant schools. ${ }^{10}$ Many jurists also interpret the preamble to the Act as an outline of the traditions of civil liberties as developed by the U.K. before 1867. In contrast, the second period - defined by numerous provincial and federal human rights legislation - strove to codify human rights in response to the national and international atrocities of the First and Second World War. ${ }^{11}$

The World Wars, the United Nation's adoption of the Universal Declaration of Human Rights (1948) and the United Nations' International Covenant on Civil and Political Rights (1966) acted as catalysts in intensifying civilian desires for a codified document which defined the basic rights of all human beings. The first human rights legislation in Canada was the Ontario Racial Discrimination Act of 1944 and was followed by a more encompassing bill of rights in the Province of Saskatchewan in 1947.12 The federal government eventually followed suit as Prime Minister J . Diefenbaker introduced the Bill of Rights, enacted in 1960. Although this Act

\footnotetext{
${ }^{10}$ Nancy Holmes, Loc. Cit.

11 Idem.

${ }^{12}$ For a complete list of provincial human rights legislation please see "Human Rights, Title 74," The Canadian Encyclopedic Digest, [Ontario] $3^{\text {rd }}$ ed., no. 14 (Toronto: Thomson Carswell Co. Ltd., 2001 ed.): 39.
} 
guaranteed "rights to life, liberty, security of person and enjoyment of property,"13 the Bill remained ineffective as it was not supported by all provinces and therefore could not become supreme law. ${ }^{14}$ Thus, the Bill of Rights, similar to the Canadian Human Rights Act (1977), was restricted to application only at the federal level and could not take precedence over other possibly discriminatory legislation at the provincial level. ${ }^{15}$ These discrepancies reflected the desire to maintain legislative supremacy and denied Canadians a consolidation of their natural rights; despite strengthening substantive human rights statues the Canadian government failed to produce a codified document which held supreme legislative authority.

During the third period of the evolution of Canadian human rights, The Canadian Charter of Rights and Freedoms was entrenched in the Constitution Act, 1982 which enhanced the legal status of the Charter and materialized the abstract notion of natural rights. Section 52 of the Constitution Act, 1982

\footnotetext{
13"Canadian Bill of Rights", in The Canadian Charter of Rights Annotated, ed. John B. Laskin, B.A., LL.B., LL.M. et al. and consulting editor The Honourable Mr. Justice Horace Krever of the Supreme Court of Ontario, (Aurora, Ontario: Canada Law Book Limited, 1982): Part 1, 3-1.

14 Nancy Holmes, Loc. Cit.

15 Idem. Moreover, each Act focuses on employment discrimination and functions as a complaint based system where the complainant must bring the discrepancy to the human rights commission or council. These administrative bodies are also retrained by legislation and the commissions or council does not hold enough power to overturn discriminatory federal or provincial legislation.
}

stated that: "The Constitution of Canada is the supreme law of Canada, and any law that is inconsistent with the provisions of the Constitution is, to the extent of the inconsistency, of no force or effect." 16 This assertion entrenched the debated notion that Canadian rights and freedoms were inalienable and impervious to social, economic or political changes. The Charter secured its authority over legislative decisions as it enhanced the scope of the judiciary and its interpretative powers of review; the courts were vested with the authority to squash legislation inconsistent with the Charter. Precedent established by Chief J ustice Dickson and other court decisions also encouraged its' "generous" rather than "legalistic" interpretation, thus broadening the courts' abilities to defend human rights and expand procedural law. ${ }^{17}$ In spite of the heightened interpretative powers entrusted to the courts, section 1 and section 33 of the Charter allow federal and provincial legislation

\footnotetext{
16 "Constitution Act, 1982", in The Canadian Charter of Rights Annotated, ed. John B. Laskin, B.A., LL.B., LL.M. et al. and consulting editor The Honourable Mr. Justice Horace Krever of the Supreme Court of Ontario, (Aurora, Ontario: Canada Law Book Limited, 1982): Part VII, General Section 52. (1). Although the Charter Act was officially entrenched, human rights were previously established by principles of common law and statues.

${ }^{17}$ For example, the courts initially nullified nineteen pieces of legislation through a broad interpretation of The Charter. This contrasts the deferential judicial use of the Bill of Rights. It must also be noted that there is a considerable amount of overlap between substantive and procedural law where the role of the courts or human rights commissions administer the state's responsibility to its' citizens; although substantive law is concerned with the actual legal rules and principles set out in various sources of law, these sources may also give rise to the creation of certain agencies which have the duty to enforce laws which set out legal rules and principles.
} 
to invalidate statutes which may override certain rights and freedoms. ${ }^{18}$ The uses of these sections, however, are restricted to certain rights and freedoms which require justification for the encroachment of these principles. ${ }^{19}$ Despite such 'checks' to prevent the abuse of the aforementioned clauses, these sections water down the Charter and diminish the powers of the courts and the inalienability of natural rights. Moreover, judicial review does not provide a 'veto' power over legislation; rather, striking down statutes produces a dialogue between the courts and government, permitting offending legislatures to be amended and reintroduced. The Charter, other federal and provincial human rights legislation, and the role of the judiciary provide a "comprehensive scheme of human rights protection and promotion" which is malleable

18 "Annotations to the Charter of Rights," in The Canadian Charter of Rights Annotated, ed. John B. Laskin, B.A., LL.B., LL.M. et al. and consulting editor The Honourable Mr. Justice Horace Krever of the Supreme Court of Ontario, (Aurora, Ontario: Canada Law Book Limited, 1982): Application of Charter Section 33. (1-5) and Constitution Act, 1982, Part I, sec. 1.Guarantee of Rights and Freedoms,. The Notwithstanding Clause of the Canadian Charter of Rights states that Parliament or a provincial legislature may declare an Act of Parliament or of the legislature to "operate notwithstanding a provision included in section 2 or sections 7 to 15" of the Charter." However, the declaration will become ineffectual after five years where it may be reenacted.

${ }^{19}$ Andree Lajoie and Henry Quillinan, "The Supreme Court Judges' Views of the Role of the Courts in the Application of the Charter," in Protecting Rights and Freedoms: Essays on the Charter's Place in Canada's Political, Legal, and Intellectual Life, ed. Philip Bryden et al. (Toronto: University of Toronto Press Incorporated, 1994): 95-96. The Oaks Test provides certain standard where the government is required to defend its' legislation as reasonable and justified in the violation of the constitutionalized rights or freedoms. In addition, Section 1 guarantees the rights and freedoms subject to "reasonable limits prescribed by law as can be demonstrably justified in a free and democratic society." and adaptive as it reacts to economic, social and political changes. ${ }^{20}$

\section{History of Terrorism and Canadian Legislation}

The consequences of the September 11, 2001 terrorist attacks on the United States produced immediate and profound effects on Canadian society. Although this was not the first time Canada experienced internal or external threats of terrorism, the results of Canada's decision to join the "war on terrorism" heightened Canadian political and social insecurities and fear. ${ }^{21}$ Similar to the violation of J apanese-Canadian rights during World War II and the 1970 October Crisis in Quebec, the Anti-Terrorism Act (2001) represented a "permanent change to Canadian criminal law" where minority groups feared that they would be disproportionably impacted."22

The War Measures Act allowed for the Royal Canadian Mounted Police (RCMP) to arbitrarily arrest Canadian citizens without providing criminal charges and ignored the principle of habeas corpus, among other

\footnotetext{
20 Nancy Holmes, Loc. Cit.

${ }^{21}$ Reg Whitaker, "Before September 11 - Some History Lessons," in Terrorism, Law and Democracy How is Canada changing following September 11?, ed. David Daubney, B.A., LL.B. et al., (Montreal, Quebec: Les Editions Themis, 2002): 41.

${ }^{22}$ Kent Roach, September 11 Consequences for Canada (Montreal \& Kingston: McGill - Queen's University Press, 2003), 59.
} 
violations of rights and freedoms. ${ }^{23}$ Although this Act permitted far-reaching powers for law enforcers and the government, this temporary encroachment on natural rights was widely accepted by Canadians. Canadian citizens justified government action and the restriction of certain rights and freedoms as a reasonable response to threats of war or terror. Yet, due to dissent among certain groups following the October Crisis of 1970, the War Measures Act was repealed and replaced by the Emergencies Act (1985). This new Act balanced the government's sweeping powers precise definitions and recommendations, the establishment of a civilian agency guided by strict legal objectives to oversee the implementation of the Act, and a complex system of accountability and review over the Act's declaration, interpretation and application. ${ }^{24}$

\section{Prior to September 11 and the speedy} introduction and assent of Bill C-3625, Canada relied largely on criminal legislation and the

\footnotetext{
${ }^{23}$ Reg Whitaker, Loc. Cit., 43-44.

24 Ibid, 50-51 and Department of Justice of Canada, "Emergencies Act ( R.S., 1985, c. 22 (4th Supp.))," Consolidated Statutes and Regulations, September 27, 2005, http://laws.justice.gc.ca/en/E4.5/index.html (accessed March 3, 2006). This Act is also consistent with the Charter as the limitations imposed on Canadian rights are proportional to the benefits that such restrictions may incur to maintain Canadian security. Moreover, this Act enhanced procedural law as it created many agencies to ensure its appropriate administration.

25 This bill was given assent on December 18, 2001 and brought into force December 24, 2001 as the Anti-Terrorism Act. However, to avoid confusion the Act will be referred to as Bill C-36.
}

Emergencies Act to address terrorism and terrorist activities. Such bodies remedied acts such as hostage-taking and aircraft hijacking while establishing provisions for maritime navigation and the protection of nuclear material. ${ }^{26}$ The Immigration Act, in addition to the Criminal Code, was amended to deal with terrorism and security concerns, yet the definition of "terrorist acts" was not established. This reflected the difficulty involved in creating a widely accepted definition which balanced the respect for human rights and the need for effective legislation. ${ }^{27}$ This was met with Bill C-36 which proposed to define such contentious terminology while also broadening ministerial powers and establishing new criminal offences. ${ }^{28}$

During the Bill's introduction to Parliament and following its assent, scholars, minority groups, union leaders and Canadian citizens highlighted many flaws in Bill C-36

\footnotetext{
${ }^{26}$ Richard G. Mosley, "Preventing Terrorism Bill C-36: The Antiterrorism Act 2001," in Terrorism, Law and Democracy How is Canada changing following September 11?, ed. David Daubney, B.A., LL.B. et al., (Montreal, Quebec: Les Editions Themis, 2002): 148.

${ }^{27}$ Kent Roach, 29 and Richard G. Mosley, 147-148. Before September 11 the last reference made to terrorism was in section 98 of the Criminal Code which responded to the World War Red Scare and the Winnipeg General Strike.

${ }^{28}$ Don Stuart, "The Anti-terrorism Bill (Bill C-36): An Unnecessary Law and Order Quick Fix that Permanently Stains the Canadian Criminal Justice System," in Terrorism, Law and Democracy How is Canada changing following September 11?, ed. David Daubney, B.A., LL.B. et al., (Montreal, Quebec: Les Editions Themis, 2002): 175.
} 
including the fact that its definitions of

"terrorist activity" are too broad and may be applied too generally. Such definitions may justify government violation of numerous natural rights such as the freedom of conscience and religion, freedom of belief, and freedom of expression, the freedom of peaceful assembly and association. ${ }^{29}$ These concerns instigated a politically charged debate over the fluidity of Canadian rights and freedoms or natural rights and the role of the government in protecting such principles. ${ }^{30}$

\section{Criminalizing Terrorism: Bill C-36}

Context in Which Bill C-36 was Constructed and the Powers it Asserted

Following the tragic aftermath of September 11, 2001, international bodies such as the United Nations sought to establish a definition of terrorism and codify it into international agreements and national statues. ${ }^{31}$ While these efforts at the international level remained unsuccessful, the Canadian Government rectified this 'gap' in Canadian legislation through enacting Bill C-

\footnotetext{
29 "Annotations to the Charter of Rights," in The Canadian Charter of Rights Annotated, ed. John B. Laskin, B.A., LL.B., LL.M. et al. and consulting editor The Honourable Mr. Justice Horace Krever of the Supreme Court of Ontario, (Aurora, Ontario: Canada Law Book Limited, 1982): Part I Fundamental Freedoms section 2 (a-d).

30 Don Stuart, Loc. Cit., 179-180.

${ }^{31}$ Richard G. Mosley, Loc. Cit., 148-149. The most recent attempts by The General Assembly's Ad Hoc Committee on Terrorism, spearheaded by the UN, established only narrow definitions of particular terrorist activities. These definitions have not been widely used however the UK and US have already enacted anti-terrorist legislation and regimes.
}

36. ${ }^{32}$ Bill C-36, as stated in its summary, amended "the Criminal Code, the Official Secrets Act, the Canada Evidence Act, the Proceeds of Crime (Money Laundering) Act and other Acts, and [enacted] measures respecting the registration of charities [through the Charities Registration (Security Information) Act], in order to combat terrorism." 33 In addition, the National Defense Act was amended "to clarify the powers of the Communications Security Establishment to combat terrorism." 34 Many of these amendments extended jurisdictional powers to meet the objectives as outlined by the United Nations Security Council Resolution 1373.

\section{The United Nations Security Council} played a strong role in soliciting the need for anti-terrorism legislation in both the international and national realm. Resolution 1373 created the standards by which governments were to establish their respective

\footnotetext{
32 Richard G. Mosley, Loc. Cit., 150.

33 Joyce Fairbairn, "The Special Senate Committee on Bill C-36: First Report," Report of the Committee, November 1, 2001, http://www.parl.gc.ca.remote.libproxy.wlu.ca/37/1/parlbus/commbus/s enate/com-e/sm36-e/rep-e/rep010ct01-e.htm (accessed March 3, 2006) and House of Commons of Canada, Bill C-36. First Session, Thirty-seventh Parliament, 29-50 Elizabeth II, 2001, Parliamentary Publication, http://www.parl.gc.ca (accessed March 3, 2006): Recommendation and Summary. The following are other amended acts of Bill C-36: Access to Information Act, Canadian Human Rights Act, Canadian Security Intelligence Service Act, Corrections and Conditional Release Act, Federal Court Act, Firearms Act, National Defense Act, Personal Information Protection and Electronic Documents Act, Privacy Act, Seized Property Management Act and United Nations Act.

${ }^{34}$ House of Commons of Canada, Bill C-36: Recommendation and Summary.
} 
laws and these requirements were met by Bill C-36. The aim of Resolution 1373 and Bill C-36 was to prevent and suppress the financing of terrorist acts, criminalize the voluntary provision or gathering of funds to be used to perform terrorist acts, restrict the funds and other economic properties or resources used to execute or to assist terrorist acts, disallow the making accessible of all types of resources or services for the purpose of carrying out terrorist activities, and stop the recruitment of terrorist groups and stop the supply of arms to terrorists. ${ }^{35}$ These objectives, encompassed through the numerous amendments set out by Bill C-36, intend to balance Canadian security with the encroachment of natural rights outlined by the Charter. ${ }^{36}$

\section{Summary of Bill C-36}

The preamble of Bill C-36 defines the Bill's objectives as it states that the Parliament of Canada recognizes terrorism as a national concern and that the measures prescribed seek to "protect Canadians against terrorist activity while continuing to respect and promote the rights and freedoms guaranteed by the Canadian Charter of Rights and Freedoms." 37 This concern reflects the fact that the Bill provides some restrictions on the government

${ }^{35}$ Richard G. Mosley, Loc. Cit., 151.

${ }^{36}$ Although there are several pieces of legislation at both the federal and provincial level this analysis of Bill C-36 will focus on The Charter as it holds supreme authority in Canadian law.

${ }^{37}$ House of Commons of Canada, Bill C-36: Preamble. as it not only requires reasonable grounds to list suspected groups or charities who support terrorist activities but also demands that federal or provincial prosecutors prove beyond a reasonable doubt that a "terrorist act was committed."38 In addition, numerous review procedures - as suggested by The Special Senate Committee's "First Report on Bill C-36" and "Second Report on Bill C-36" - have been implemented to oversee and restrain the use of the Bill. ${ }^{39}$ Conversely, new mechanisms have been created allowing the "freezing, seizure, restraint and forfeiture" of properties as well as "forced disclosure" to the RCMP and Canadian Security Intelligence Service of any information relating to the property owned on behalf of a terrorist group. ${ }^{40}$ Arrests and detentions may proceed based solely on suspicion without obtaining warrants or evidence. ${ }^{41}$

Bill C-36 makes it a criminal offence to collect, provide or make financial or other resources available for terrorist activities, to participate in or contribute to terrorist

\footnotetext{
38 Kent Roach, Loc. Cit., 25.

39 Joyce Fairbairn, "The Special Senate Committee on Bill C-36: First Report" and Kent Roach, 66. The Special Committee suggested several changes in the Bill where most were supported. Some changes included judicial review, five-year sunsets on investigative hearings and preventive arrests, and the creation of annual reports on the use of the abovementioned powers.

${ }^{40}$ Richard G. Mosley, Loc. Cit., 160.

${ }^{41} \mathrm{Ibid}, 161$. Part XII.2 of the Criminal Code requires that unwarranted seizures be fully compensated and that the release of property is required for the person(s) to maintain reasonable living, business and legal expenses as well as meeting the bail requirements.
} 
activities, to teach or encourage anyone to

facilitate terrorist activities, and to protect or conceal a terrorist. ${ }^{42}$ Despite such new changes to the aforementioned Acts, new investigative trials reflect similar procedural laws as found in the Criminal Code; suspects are protected with legal safeguards such as the right to legal counsel and protection against selfincrimination. However, legal charges need not to have been laid against the suspect prior to or during the hearing. Furthermore, the Bill allows for the arrest and detention of a person who is suspected of participating in or preparing to commit a terrorist activity despite the fact that there are insufficient grounds to arrest and charge the suspect. ${ }^{43}$ Although these enhanced government powers remain highly contentious, most debate surrounds the terminology and new definition of "terrorist activities". This is the focus of political and civilian debate as these definitions are incorporated into all aspects of the Bill and as a general definition allows for the possible classification of anti-globalization protests, civilian dissent and labour strikes as "terrorist activities".44

\section{Terrorist Offenses: A Broad Definition}

\footnotetext{
42 House of Commons of Canada, Bill C-36: Part 1, sec. 2-23. and sec. 23.1.

${ }^{43}$ Richard G. Mosley, Loc. Cit., 169. This section of the Bill is tempered by strictly defined circumstances and brief periods of detention where detention beyond 48 hours may be subject for review.

${ }^{44}$ Kent Roach, Loc. Cit., 33-34.
}

Many judges, such as Chief J ustice Beverley McLachlin, recognized that Bill C-36 would require a readjustment of the balance held between liberty and national security. ${ }^{45}$ This readjustment would translate into unpopular restraints on natural rights and demonstrate the fact that the Charter's rights are malleable under certain social and political variables. The Bill is consistent with the Charter as the requirements of fairness are fulfilled and as its implementation is not resistant to any Charter challenges. ${ }^{46}$ Yet, some argue that this compliance can easily be violated as the Bill's definition of "terrorist activities" allows for the extension of political powers outside the context of terrorism. ${ }^{47}$

The term "terrorist" contains an undeniable level of ambiguity as legal scholars, politicians and civilian opposition groups assert the difficulty in distinguishing between the term "terrorist activities" and civilian

\footnotetext{
45 Kent Roach, Loc. Cit., 29.

46 Irwin Cotler, "Constitutional Democracy: Balancing Security and Civil Liberties," in Terrorism, Law and Democracy How is Canada changing following September 11?, ed. David Daubney, B.A., LL.B. et al., (Montreal, Quebec: Les Editions Themis, 2002): 230.

${ }^{47}$ Kent Roach, Loc. Cit., 58-59, 77 and 98. Many civil groups representing legal scholars and civil libertarians asserted their concern over the Bill's inconsistency with legal principles and protections as well as the Bill's ability to disproportionately impact certain minority groups. Others also asserted that despite the notion that the Bill is "Charter proof" for innocent citizens it still infringes on the rights of possible terrorists. These, among other concerns, such as the police force's increasing powers, will not be discussed in detail as this requires extensive analysis as it violates other aspects of the Charter.
} 
protest. 48 "Terrorist activity" and "terrorist group" are defined in Part II.1, section 83.01 of the Bill. Despite the Act's lengthy definition of "terrorist activities", dissenters point to the phrase found in (b)(i)(A): "a political, religious or ideological purpose, objective or cause" to emphasis the ambiguity of the Bill. Likewise, the definition of "terrorist activities" in (b)(ii)(E) allows for a broad interpretation and possible encroachment on certain Charter rights as it criminalizes:

[...] those who intend to cause serious interference with or serious disruption of an essential service, facility or system, whether public or private, other than as a result of advocacy, protest, dissent or stoppage of work that is not intended to result in the conduct or harm referred to in any of clauses (A) to (C) [this includes planning to cause a serious danger to the safety of the public]. ${ }^{49}$

\section{Advocates for the abolishment of this}

legislation argue that despite the removal of the term "lawful protests" from the definition, as recommended by the Special Senate Committee on Bill C-36, the assessment of who

\footnotetext{
${ }^{48}$ Luigi Bonanate, "Some Unanticipated Consequences of Terrorism," Journal of Peace Research 16, no.3 (1979): 197-198. Luigi Bonanate discusses the fact that the term "terrorist" is a social construct where every political group may justify the use of violence for example - in the right to self defense. However, no political groups would identify themselves as "terrorists", yet, the action of "the other" would, in the same case, be identified as "terrorism". 49 House of Commons of Canada, Bill C-36: Interpretation Part II.1, sec. 83.01 .
}

may be a terrorist is debated in private and only requires reasonable grounds for conviction instead of actual proof in a court of law. ${ }^{50}$ Moreover, any serious disruption of essential private or public services which may result in a serious risk to public safety - such as a striking nurses' union - may be classified as a terrorist act despite its lawfulness. ${ }^{51}$ In addition, Parliament's definition of "terrorism" as a "threat [...] to commit any such act or omission" blurs the line between expressions of a strong religious or political opinion and a terrorist threat. ${ }^{52}$ The classification of "terrorist activities" or "terrorism" goes beyond any previous national or international attempts to criminalize possible terrorist threats or actual behaviours. Although many groups vehemently opposed the Bill's assent, the objectives of its contractors, and through the establishment of procedural law, protects the rights of the possible targets of terrorism and maintains security for Canadian citizens.

\footnotetext{
50 Don Stuart, Loc. Cit., 178. The authorities do not have to wait for an act of a terrorism to charge a person. In addition, the person may be convicted because he/she assisted the escape of a terrorist, agreed to help a terrorist or attempted to assist terrorism. 51 Ibid, 181 and Kent Roach, Loc. Cit., 34-35. Scholars such as Don Stuart asserts that labour union strikes, passive resistance that may disrupt every day society, anti-globalization protestors, aboriginal groups' obstruction of logger or mining roads to declare aboriginal title, sending relief to an Afghanistan refugee group that may be discovered to be involved in terrorist activities and the unknowing sponsorship of a Muslim terrorist are all activities which may be targeted by the Bill and is severely punishable.

52 Kent Roach, Loc. Cit., 35.
} 
The establishment of certain provisions such as judiciary review and a committee of Parliament to conduct an in-depth analysis of the operation of the Bill have been integrated into Bill C-36 to safeguard against possible abuses. Thus, the Bill advances the natural rights of individuals and reaffirms the principles of the Charter as the Bill ensures that all citizens, regardless of race, religion or ethnic origin, have the equal right to "enjoy the security, protections and liberty shared by all Canadians".53

Bill C-36: Balancing Canadian Natural Rights and National Security

The Charter protects various rights, however, by virtue of section I, these rights are limited. This allows Bill C-36 to comply with the Charter and, at the same time, place reasonable and justified limits on Canadian rights. The Minister of J ustice when introducing the Bill stated that the Charter does not suggest that natural rights are absolute, rather the role of the courts and government is to strike a balance between limiting the rights of individuals and maintaining national security. ${ }^{54}$ The argument that the Bill restrains courts as judges must make decisions without the presentation of all information or evidence is countered as courts have demonstrated their independence and

53 Kent Roach, Loc. Cit., 79.

$54 \mathrm{Ibid}, 88$. tolerance of dissent in cases such as Burns and Rafay. ${ }^{55}$ In addition, the Bill has enshrined a system of checks and balances. Consent from the Attorney General must be obtained before a peace officer may present to provincial or federal courts, with reasonable grounds, that a terrorist activity may be committed. ${ }^{56}$ Prior to the assent of Bill C-36, the recommendations set out by The Special Senate Committee were amended; reviews and a "sunset clause" were incorporated into the Bill to restrain the sweeping powers of prosecutors and control the possible abuse of the definitions of "terrorist activities."

The addition of the sunset clause creates a five year time limit on the trial and investigative powers of the government. ${ }^{57}$ The renewal of these powers requires a full Parliamentary debate where Canadian citizens, through the power of their vote, may influence the outcome of the clauses' renewal. In addition to this provision, the Bill requires a complete review and annual report on the operation of the Bill in which the Attorney General of Canada and the Solicitor General of Canada must present their findings to Parliament. The Bill must comply with the norms of International Human Rights and is subject to the oversight of the Information and

\footnotetext{
55 Kent Roach, Loc. Cit., 114.

${ }^{56}$ Richard Mosley, Loc. Cit., 169.

57 Wayne MacKay, Loc. Cit., 69.
} 
Privacy Commissioners. ${ }^{58}$ A 'policing'

mechanism is created as these commissioners require strict observance of certain natural rights and as annual reports are available to the public. This allows for civic debate and scrutiny; in turn, through lobbying the government, supporting government opposition or through a court's decision that certain aspects of the Bill violate the Charter, the Anti-Terrorism Act may be repealed. 59

\section{Assessment}

Bill C-36 is a significant component of the Federal Government's commitment to fighting terrorism. Moreover, the abovementioned provisions take into account the objectives of protecting national security through defining "terrorist activities" while also respecting the values of the Charter. ${ }^{60}$ As the preamble of Bill C-36 states, its intent is to enhance the most fundamental rights - "the right to life, liberty and security of the person"while simultaneously operating within the confines of the Charter. Certain rights become malleable depending on the political and social context in which they are exercised. The maintenance of one's fundamental rights may require the encroachment of other freedoms

\footnotetext{
58 Gwen Boniface, "Does Bill C-36 Give Police too Many Powers?," in Terrorism, Law and Democracy How is Canada changing following September 11?, ed. David Daubney, B.A., LL.B. et al., (Montreal, Quebec: Les Editions Themis, 2002): 233.

${ }^{59}$ Richard Mosley, Loc. Cit., 170-171.

60 Ibid, 172.
}

such as the "freedom of conscience and religion, the freedom of belief, the freedom of expression, the freedom of peaceful assembly and association". 61

Civil liberties groups have condemned Bill C-36 as a powerful tool for the arbitrary suspension of natural rights. Most Canadians, however, have supported such possible restrictions when faced with threats of terrorism. For example, during the October 1970 Crisis, 58 percent of Canadians asserted that the threat of terrorism overshadowed restraints on rights and freedoms. ${ }^{62}$ Similarly, following the September 11 attacks, most Americans were willing to exchange their civil liberties for security. ${ }^{63}$ Thus, during periods of national trauma, some Canadian citizens may allow for flexibility in the interpretation of their perceived inalienable natural rights. However, a check is maintained on such encroachments as violations of natural rights are opposed during periods of national peace and security. Bill C-36 remains unchallenged as the Canadian government and prosecutors have not breached the stated objectives of the Bill.

\footnotetext{
61 "Annotations to the Charter of Rights," in The Canadian Charter of Rights Annotated, ed. John B. Laskin, B.A., LL.B., LL.M. et al. and consulting editor The Honourable Mr. Justice Horace Krever of the Supreme Court of Ontario, (Aurora, Ontario: Canada Law Book Limited, 1982):Part I Fundamental Freedoms section 2 (a-d).

62 Kent Roach, Loc. Cit., 76.

${ }^{63}$ Darren W. Davis and Brian D. Silver, "Civil Liberties vs. Security: Public Opinion in the Context of the Terrorist Attacks on America," American Journal of Political Science 48, no. 1 (January, 2004): 28.
} 
Furthermore, Canadians continue to exercise their freedom of expression through protests, strikes and lobbying and the freedom of religious practice with no overt government discrimination against certain minority groups.

Following the assent of Bill C-36 the Act has only been used once to prosecute an $\mathrm{Al}$ Qaeda terrorist and its use did not violate the provisions of the Act or the Charter. Such infrequent use of the Bill has resulted in no case law where the Supreme Court may establish certain principles for lower courts. However, cases such as Burns and Rafay suggests that the Courts, in adjudicating terrorist cases, may exercise discretion to ensure that certain fundamental rights aren't violated. The requirements for review, the role of the courts and democratic elections restrict the possible exploitation of Bill C-36. Due to the fluidity of Canadian individual rights, which are shaped by political and social influences, the Canadian Government has successfully reacted to the threats of terrorism. 


\section{Bibliography}

"Annotations to the Charter of Rights." In The Canadian Charter of Rights Annotated, edited by J ohn B. Laskin, B.A., LL.B., LL.M. et al. and consulting editor The Honourable Mr. J ustice Horace Krever of the Supreme Court of Ontario. Aurora, Ontario: Canada Law Book Limited, 1982.

Bonanate,Luigi. "Some Unanticipated Consequences of Terrorism." J ournal of Peace Research 16, no. 3 (1979): 197-211.

Boniface, Gwen. “Does Bill C-36 Give Police too Many Powers?” In Terrorism, Law and Democracy How is Canada changing following September 11?, edited by David Daubney, B.A., LL.B. et al. Montreal, Quebec: Les Editions Themis, 2002.

Rt. Hon. Campbell, Kim. “Parliament's Role in Protecting the Righstr and Freedoms of Canadians.” In Protecting Rights and Freedoms: Essays on the Charter's Place in Canada's Political, Legal, and Intellectual Life, edited by Philip Bryden et al. Toronto: University of Toronto Press Incorporated, 1994.

Canadian Bill of Rights. In The Canadian Charter of Rights Annotated, edited by J ohn B. Laskin, B.A., LL.B., LL.M. et al. and consulting editor The Honourable Mr. J ustice Horace Krever of the Supreme Court of Ontario. Aurora, Ontario: Canada Law Book Limited, 1982.

Constitution Act, 1982. In The Canadian Charter of Rights Annotated, edited by J ohn B. Laskin, B.A., LL.B., LL.M. et al. and consulting editor The Honourable Mr. J ustice Horace Krever of the Supreme Court of Ontario. Aurora, Ontario: Canada Law Book Limited, 1982.

Cotler, Irwin. "Constitutional Democracy: Balancing Security and Civil Liberties." In Terrorism, Law and Democracy How is Canada changing following September 11?, edited by David Daubney, B.A., LL.B. et al. Montreal, Quebec: Les Editions Themis, 2002.

Davis, Darren W. and Brian D. Silver. "Civil Liberties vs. Security: Public Opinion in the Context of the Terrorist Attacks on America." American J ournal of Political Science 48, no. 1 (J anuary, 2004): 28-46.

Department of J ustice of Canada. “Emergencies Act ( R.S., 1985, c. 22 (4th Supp.) ).” Consolidated Statutes and Regulations, September 27, 2005. http://laws.justice.gc.ca/ en/E-4.5/ index.html (accessed March 3, 2006).

Fairbairn, J oyce. "The Special Senate Committee on Bill C-36: First Report." Report of the Committee, November 1, 2001. http:// www.parl.gc.ca.remote.libproxy.wlu.ca/37/ 1/parlbus/commbus/ senate/com-e/ sm36-e/ repe/ rep01oct01-e.htm (accessed March 3, 2006).

Fairbairn, J oyce. “The Special Senate Committee on Bill C-36: Second Report." Report of the Committee, December 10, 2001.

http:// www.parl.gc.ca.remote.libproxy.wlu.ca/37/ 1/parlbus/commbus/ senate/ com-e/ sm36-e/repe/ rep02dec01-e.htm (accessed March 3, 2006). 
Holmes, Nancy. "Human Rights and the Courts in Canada." Law and Government Division, Depository Services Program, October 2001. http:// dsppsd.pwgsc.gc.ca.remote.libproxy.wlu.ca/ Collection-R/LoPBdP/BP/bp279-e.htm (accessed March 3, 2006).

House of Commons of Canada. Bill C-36. First Session, Thirty-seventh Parliament, 29-50 Elizabeth II, 2001. Parliamentary Publication. http:// www.parl.gc.ca (accessed March 3, 2006).

"Human Rights, Title 74." The Canadian Encyclopedic Digest, [Ontario] 3 $3^{\text {rd }}$ ed., no. 14. Toronto: Thomson Carswell Co. Ltd., 2001 ed.

Lajoie, Andreé and Henry Quillinan. 'The Supreme Court J udges' Views of the Role of the Courts in the Application of the Charter." In Protecting Rights and Freedoms: Essays on the Charter's Place in Canada's Political, Legal, and Intellectual Life, edited by Philip Bryden et al. Toronto: University of Toronto Press Incorporated, 1994.

MacKay, Wayne. "Regulating Freedom of Expression the Canadian Way." In Canadian Constitutional Dilemmas Revisited, edited by Denis N. Magnusson and Daniel A. Soberman. Kingston, Ontario: Institute of Intergovernmental Relations, 1997.

Mosley, Richard G. “Preventing Terrorism Bill C-36: The Anti-terrorism Act 2001.” In Terrorism, Law and Democracy How is Canada changing following September 11?, edited by David Daubney, B.A., LL.B. et al. Montreal, Quebec: Les Editions Themis, 2002.

Roach, Kent. September 11 Consequences for Canada. Montreal \& Kingston: McGill - Queen's University Press, 2003.

Stuart, Don. "The Anti-terrorism Bill (Bill C-36): An Unnecessary Law and Order Quick Fix that Permanently Stains the Canadian Criminal J ustice System." In Terrorism, Law and Democracy How is Canada changing following September 11?, edited by David Daubney, B.A., LL.B. et al. Montreal, Quebec: Les Editions Themis, 2002.

Whitaker, Reg. "Before September 11 - Some History Lessons." In Terrorism, Law and Democracy How is Canada changing following September 11?, edited by David Daubney, B.A., LL.B. et al. Montreal, Quebec: Les Editions Themis, 2002. 